\title{
Impact of Financial Sector on Economic Growth: Evidence from Kosovo
}

\author{
Majlinda Mazelliu, MBA
}

majlinda.mazelliu@gmail.com

\author{
Jeton Zogjani, MSc \& MBA
}

zogjanijeton@gmail.com

\author{
Doi:10.5901/mjss.2015.v6n6s4p315
}

\begin{abstract}
Financial sector is world-wide considered the core component of the economic growth (Greenwood, 2013). This paper aims to present the impact of financial sector on economic growth in Kosovo, during the period 2008 until 2014. The main theoretical arguments for discussion and analysis are focused on the problems and challenges of financial sector in Kosovo under former Yugoslavia, the main process of establishment of financial sector in Kosovo in post war period, overall structure of financial sector in Kosovo, the effect of financial global crisis on financial sector particularly on foreign capital / investors in banking system and other factors that have impacted reduction of the annual rate of financial sector in 2010 and 2011. In the methodology of this research are used secondary data, which are calculating through STATA program and as the main analyses in the paper are descriptive statistic, OLS method and correlation matrix. The results of analyses have shown that financial sector has positive impact and positive correlation with Kosovo's economic growth, inflation rate has positive impact and positive significance on economic growth and exchange rate has negative impact and non - significance in economic growth in the period 2008 - 2014. As a result the research concludes that financial sector should play a crucial role in Kosovo's economy because its participation in GDP is too high (together with FDI and remittance they participate about $60 \%$ of Kosovo's $\mathrm{GDP})$. Regardless of decrease of financial sector in last few years (it is as result of reflection of global crisis in Kosovo), it is very important for the financial sector to continue to increase further its participation in overall economy of Kosovo.
\end{abstract}

Keywords: banking sector, foreign capital, inflation rate, OLS method, STATA.

\section{Introduction}

The impact of financial sector in economic growth is considered vital for the economies as the financial sector or intermediaries play an important role in mobilizing the funds "to the highest-valued users in the economy" (Greenwood, 2013). According to Levin (2004) in Zhuang et.al., (2009) the countries with well developed financial sector services tend to grow faster. On the other hand, according to Zhuang et.al., (2009) other researchers argue that "there is significant disagreement on the finance-growth nexus providing different arguments that the finance doesn't cause growth but rather it responds to demands from the real sector (Joan Robinson (1952), while the Nobel Laureate Robert Lucas (1988) also dismisses finance as an 'over-stressed' determinant of economic growth".

The financial sector of Kosovo has been established during the years of autonomy and until 1989, Kosovo has had the state owned Central Bank of Kosovo, but its authority in Kosovo financial system was very limited because financial policies were under strong control from the financial system and government policies of the then Yugoslavia (later from Serbia). From 1990 until the war (1999) there was no any financial institution in Kosovo because Serbian government has controlled and monitored Kosovo forcibly in every political and financial institution. After the war, in 1999 Kosovo has established financial institution and the banking sector, whose progress of development and growing has reached extraordinary results up to date. According to Bell ( 2005), financial sector in Kosovo is one of the most developed sectors in the Kosovo's economy, during last decade the banking market of Kosovo is considered to have been grown very fast and new entries in the banking sector have continued even in 2014 (especially banks with foreign capital). According to BQK Report (2015), in the year 2014, financial sector in Kosovo has had an annual growth of $7.3 \%$ (in 2013 is over 10\%) and the total value of assets in financial sector has achieved 4.5 milliard $€$. Moreover, according to the World Bank Report (2013), the total assets in financial system as a share of Kosovo's GDP is doubled for one decade, it has been $33 \%$ of GDP in 2003 and in 2012 it has reached in $74 \%$ of Kosovo's GDP. Thus, this research paper answers to the question whether the impact of financial sector on economic growth in Kosovo and this is made through analysis of arguments and data that present the progress of financial sector in Kosovo 2010 - 2011. 


\subsection{Objectives of the research}

The main objective of this research is to empirically analyze the impact of financial sector on economic growth in Kosovo for the period 2008 until 2014. Whereas, the specific objectives relate to: a) providing theoretical arguments on the structure of the financial sector and economic growth in Kosovo, under former Yugoslavia and the post war period; and b) to measure whether the impact of the financial sector in economic growth of Kosovo for the period 2008-2014 has been positive.

Thus, the hypothesis of this research paper is: financial sector of Kosovo has positive impact on economic growth of the country.

In order to reach the above mentioned objectives, this research will focus on addressing the following questions: how is structured the financial sector and financial intermediary in Kosovo? What is the correlation between financial sector and economic growth in Kosovo? What is the role of global crisis in the financial sector in Kosovo? How do other factors affect financial sector and its impact on economical growth of Kosovo?

This research is organized in five sections. The next Section 2. will provide an overview of the financial sector in Kosovo, followed by Section 3. where will be provided the used methodology and econometric model. Section 4. will present empirical results and interpretation of findings and the last Section 5. will answers to the above raised questions and will provide the conclusion.

\section{Literature Review}

Upon the end of war in Kosovo in 1999, financial system in Kosovo is facing with many challenges and problems that are virtually destroyed by the Serbian government, and until establishment of the financial institutions and banking sector in Kosovo has existed a financial gap. According to BQK reports the process of establishment of financial institutions in Kosovo has been very challenging and has been accompanied with different difficulties but the presence of credible international institutions such as: IMF, WB and USAID has supported the sector with their financial experience in establishment of financial institutions. According to BQK Report (2010), international institution in Kosovo (UNMIK), on 15 November 1999 has approved the Regulation no. 1999/20 on establishment of the Banking and Payments Authority of Kosovo (BPK), which as a financial institution had to and had proceeded with building and strengthening of the banking system in Kosovo. On the other hand, insurance activities from non-banking institutions are approved by UNMIK with the Regulation no. 2001/25, this regulation included licensing, supervision and regulation of insurance companies and insurance in general, (World Bank Report, 2015). Then, until 2000, financial sector is categorized by three main processes: a) establishment of the banking institutions; b) implementation of the reforms in financial system; c) empowerment of the financial institutions and growth of their efficiency. The Table (1) below provides more details about the structure and overview of financial sector in Kosovo in 2014.

Table 1: Overall Structure of Financial System in Kosovo (2014)

\begin{tabular}{|l|c|c|c|}
\hline & No of Institutions & Value of Assets (mill. $€$ ) & Total Assets (\%) \\
\hline A) Banking Sector & 10 & 3.200 & $70.1 \%$ \\
\hline Foreign Banks & 8 & 2.890 & 66 \\
\hline Domestics Banks & 2 & 310 & 9 \\
\hline B) Non - Banking Sector: & 76 & 1.362 & $\mathbf{2 9 . 9 \%}$ \\
\hline Pension Fund & 2 & 1.100 & 24.1 \\
\hline Insurance Companies & 14 & 140 & 3.1 \\
\hline Micro-Financial Institutions & 18 & 113 & 2.5 \\
\hline Financial auxiliaries & 42 & 9 & 0.2 \\
\hline Total: & 86 & 4.562 & $100 \%$ \\
\hline
\end{tabular}

\section{Source: CBK-BQK 2015}

The financial sector in Kosovo is categorized as one of the newest financial sector in SEE countries, and it has began to develop in 2000, (Ramosaj, 2010). Moreover, financial sector constitutes from banking sector and non - banking sector, the first has over $70 \%$ of financial market while the second has nearly $30 \%$ of financial market (table 1) and this structure has dominated as of the beginning of financial sector. Financial sector in Kosovo is very attractive for foreign 
investors, because in every year are seen new entries with foreign capital / investors. According to CBK-BQK Report (2015), the number of commercial banks, insurance companies and financial auxiliaries with foreign capital is continuously increasing from 2011 - 2014 and in 2014 over $90 \%$ of banking capital is constituted by foreign capital and over $92 \%$ of assets in micro-financial market are also of the foreign capital. According to Rllnvest Institute (2009) the value of assets in insurance industry has increased for more than 53\% only for two years from 2005 to 2007 (from 46.2 million $€$ in 2005 to over 70 million $€$ in 2007) and the insurance industry had its participation in the total financial sector assets with around $5 \%$ in 2007. Also, the pension fund has increased its share with over $5 \%$ in the total assets of financial sector (from from 19 \% in 2012 to $24.1 \%$ in 2014), (World Bank Report, 2013, \& CBK-BQK Report, 2015).

If we refer to the trend of the financial sector and economic growth in Kosovo since the post-war period, we can understand that the financial sector has increased continuously, during this period but on the other hand, economic growth has increased and decreased during this period. Thus researches argue that economic growth in Kosovo has been $16.6 \%$ in 2001 but annual economic growth in 2002 has decreased with - $2.6 \%$ and with - $1.1 \%$ in 2002, (Gubbels et al, 2007). They consider that the highest economic growth in Kosovo in 2001 has occurred as a result of international financial support and different financial funds for reconstruction and development of Kosovo's economy and in 2002 these financial support has dramatically declined. International institutions on the other hand argue that the best side in this period is that Kosovo has achieved to have positive economic growth during financial global crisis but projection for the future indicates that Kosovo will stand economy in the same trend of growth (over $3.5 \%$ annual growth) till 2017, (World Bank Report, 2013). Financial sector in Kosovo from the beginning has proved to be very successful and in every year until 2009 financial sector has exceeded expectations. However, even though many international institutions argue that Kosovo has not been affected by the global financial crises (World Bank Report, 2013), many researchers (Zogjani \& Kelmendi, 2015; Ramosaj, 2010) argue that since the global financial crisis has affected developed countries, it has affected indirectly even the financial sector (particularly on banking sector) in Kosovo, where most of foreign investors in financial sector come from these countries.

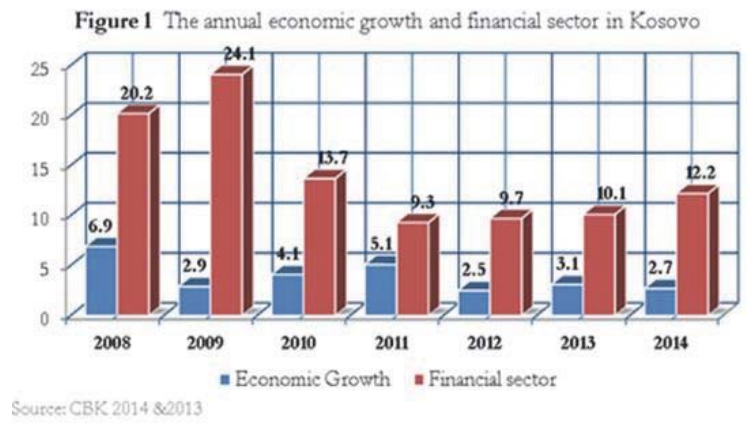

Moreover, Ramosaj (2010) has noted that global financial crisis has penetrated in financial sector in Kosovo (particularly in banking sector) through three (3) main pillars: a) inadequate management of credit risk and their liquidity; b) liberalization of excessive lending policies; $c$ ) inadequate capitalization of the banking institutions. According to CBK-BQK Report (2011), banking sector is the most attacked sector in financial system in Kosovo from financial global crisis and in total structure of assets, the main element that have declined in 2010 are as following: cash, balance with CBK and with commercial banks, fixed assets and other assets; then in the same year, commercial banks in Kosovo have doubled their investments in the securities' market at the international financial markets from 4.4\% in 2009 to $7.1 \%$ in 2010. According to CBK-BQK Report (2012), financial sector in 2011 is considered to have declined over $4.0 \%$ and it has come as the result of decline of the balance with $\mathrm{CBK}$ - BQK with over $5 \%$ in the banking sector and total assets of the banking sector have slowed the growth in 2011. Thus these components have reflected a negative impact in overall financial sector in Kosovo in the post crisis period.

\section{Methodology and Data Collection}

In this third part of the research paper will be discussed about the main principles of methodology, such as: data collection, the quality of data, methods that are used for data calculation and the basic strategy that are used in this 
research. Data are collected from the World Bank reports and annual reports of CBK-BQK (see Appendix 1/B) and most of variables being used include period of time 2008 - 2014 (see Appendix 1/A). So, secondary data are used for analysis and the main methods are as following: Statistics Descriptive Method, OLS Method and Correlation Matrix; then all of methods are calculated by STATA program (econometric software). The research strategy in this research paper is based on the case study of financial sector in Kosovo. The main variables that are used are: economic growth (as a dependent variable) and financial sector, inflation rate and exchange rate (as independent variable). The econometric model used to analyse the correlation between dependant variable on independent variables are based on the following equation, (Nuhiu, R. \& Shala, A., 2001):

$\operatorname{Ln}(E G t)=\beta 0+\beta 1 \ln (F S t)+\beta 2 \ln (I R t)+\beta 3 \ln (E R t)+\varepsilon t$.

The main variables for analyse are as follows:

- $E G=$ Economic Growth;

- $\mathrm{FS}=$ Financial Sector;

- $\quad \mathrm{R}=$ Inflation Rate;

- $\mathrm{ER}=$ Exchange Rate;

- $\varepsilon \mathrm{t}=$ Standard Error;

- $\quad \beta 0, \beta 1, \beta 2, \beta 3$, are included in the analysis parameters;

\section{Empirical Results and Interpretations}

In this part are presented the main analysis of the research paper. In Table 2 is presented the statistical descriptive method that represents the entire data in the research paper. Most of variables that are included in research paper have 7 observations. The main analysis in table 2 are as following: the minimum value of economic growth is 2.5 (it means, the lowest value of "economic growth" in period time of research paper) and maximum value is 6.9 (it means, the highest value of "economic growth" in period time of research paper), the value of mean is 3.9 (it means, average value of "economic growth" in period time of research paper) and lastly the standard deviation values is 1.61 (it means, how many the "economic growth" variable are quite close between 2.5 to 6.9 values). The value of financial sector variable is found to be as following: the minimum is 7.4 , maximum is 24.1 then value of mean and standard deviation are 13.55 respectively 6.26. The minimum and maximum values of Inflation Rate are -2.41 repectively 9.35 , then mean and standard deviation are 3.2 and 4.02. While the exchange rate has minimum value of 102.2, maximum value of 107.2, mean value of 105.4 and standard deviation appears to be 1.63 .

Table 2: Statistics Descriptive Method

\begin{tabular}{|l|c|c|c|c|c|}
\hline Variables: & Observations & Std Derivation & Min & Mean & Max \\
\hline Economic Growth & 7 & 1.61 & 2.5 & 3.9 & 6.9 \\
\hline Financial Sector & 7 & 6.26 & 7.4 & 13.55 & 24.1 \\
\hline Inflation Rate & 7 & 4.02 & -2.41 & 3.2 & 9.35 \\
\hline Exchange Rate & 7 & 1.63 & 102.2 & 105.4 & 107.2 \\
\hline
\end{tabular}

Source: Authors estimations

In Table 3 is presented the analysis made with OLS method, which is a linear regression method and depended on calculations and it provides the results between dependent variable and independent variables. The results provided by the OLS method have found that financial sector has positive impact $(\beta 1=0.07)$ on economic growth. Explanation of the result is as following: when other independent variables in analysis are fixed and when economic growth increase per unit, it will have positive effect on financial sector with 0.07 per unit (so, it has positive impact on economic growth). Also, inflation rate has positive impact $(\beta 2=0.38)$ on economic growth but exchange rate has negative impact $(\beta 3=-0.15)$ on economic growth. Through T-statistics, we can understand the significance that the variables have between them and the significance can be positive $(T>2)$ or negative $(T<2)$. According to the results of analysis only exchange rate (6.95) has shown to have "positive" significance on economic growth. Financial Sector (0.65) and inflation rate (6.93) has shown to be non - significant (negative) $(T<2)$ on economic growth. 
Table 3: Test of Ordinary Least Squares Method

\begin{tabular}{lcccc}
\hline \hline & Coefficient & Standard Error & T-Statistic & $\mathrm{P}>\mathrm{t}$ \\
\hline Constant & 17.89 & 27.53 & 0.65 & 0.56 \\
Financial Sector & 0.07 & 0.06 & 1.07 & 0.36 \\
Inflation Rate & 0.38 & 0.05 & 6.93 & 0.01 \\
Exchange Rate & -0.15 & 0.25 & -0.60 & 0.59 \\
\hline \hline Number of Observations & 7 & & & \\
$\mathrm{~F}(3,3)$ & 21.17 & & & \\
Probability > F & 0.016 & & & \\
R - square & 0.954 & & & \\
Adjusted R - square & 0.909 & & & \\
\hline
\end{tabular}

Source: Authors estimations

Another important analysis is the $\mathrm{R}$ - square $\left(\mathrm{R}^{2}\right)$ analysis, which is a statistical measurement of the data, which should fit the regression line and according to the results presented in the Table 3 , the $\mathrm{R}$ - square is 0.95 . It means that $\mathrm{R}$ - square is close to 1.0 and in the light of theory, it indicates that the regression line perfectly fits the data that are included in the analysis, (Gingrich, P., 1997). Also, the analyses show that the adjusted R - square is 0.90 , which means that variables included in analysis are indicating a better fit. In Table 4 is presented the correlation matrix, which shows the level of correlation between dependent variable and independent variables. Based on the correlation results, the higher positive correlation has shown inflation rate with 0.89 then the financial sector with 0.32 on economic growth. But, exchange rate has shown negative correlation with -0.08 on economic growth.

Table 4: Correlation Matrix

\begin{tabular}{|l|c|c|c|c|}
\hline Variables: & Economic Growth & Financial Sector & Inflation Rate & Exchange Rate \\
\hline Economic Growth & 1.00 & & & \\
\hline Financial Sector & 0.32 & 1.00 & & \\
\hline Inflation Rate & 0.89 & -0.07 & 1.00 & \\
\hline Exchange Rate & -0.08 & -0.84 & 0.31 & 1.00 \\
\hline
\end{tabular}

Source: Authors estimations

\section{Conclusion}

In this last part of the research paper the authors have summarized the important details for financial sector and its impact on economic growth in Kosovo. The data used for analysis included period of time 2008 - 2014, and are all secondary data, while they are calculated by STATA program. The main analyses are made through the methodologies of descriptive statistic methods, regression analysis (OLS method) and correlation method. The results in OLS method have shown that financial sector $(\beta 1=0.07)$ and inflation rate $(\beta 2=0.38)$ have positive impact on economic growth of Kosovo, but exchange rate has shown negative impact $(\beta 3=-0.15)$ on economic growth. In T-statistics analysis, exchange rate (6.95) has shown positive significance $(T>2)$ on economic growth but financial sector $(0.65)$ and inflation rate (6.93) have shown negative significance $(\mathrm{T}<2)$ on economic growth. In correlation method, independent variables, such as: inflation rate (0.89) and financial sector (0.32) have shown positive correlation on dependent variable (economic growth). But, only exchange rate as independent variable has shown negative correlation with -0.08 on dependent variable (economic growth). Thus, according to the findings and results the authors conclude that financial sector in Kosovo has positive impact on Kosovo's economy in the period 2008 - 2014 proving thus the hypothesis as positive. However, this sector should increase further its impact in economic growth due to its quite high participation in GDP. Moreover, based on different official sources, financial sector together with Foreign Direct Investments (FDI) and remittances constitutes over $60 \%$ of Kosovo's GDP. 


\section{References}

CBK Report. (2010). The Banking Authority and Payments of Kosovo. Regulation No 1999/20, UNMIK - Regulation 1999/20 [Online]. Prishtina: CBK:publication Service.

CBK Report. (2011). Annual Report 2010. Prishtina: CBK: Publication Service.

CBK Report. (2012). Annual Report 2011. Prishtina: CBK: Publication Service.

CBK Report. (2015). The CBK Annual Report. Prishtina: CBK: Publication Service.

CBK Report. (n.d). Interbank Payment Systems; History. [Online]. . Prishtina: Available from: http://www.bqk-kos.org/?cid=2,59,50.

Gingrich, P. (1997). Regression. In P. Gingrich. Saskatchewan, Canada: University of Regina: Department of Sociology and Social Studies.

Greenwood J. et.al. (2012). Quantifying the impact of financial development on economic development, Review of Economic Dynamics.

Gubbels et al. (2007). The Kosovo Pension Pension Reform: Achievements and Lessons .

Nuhiu, R. \& Shala, A. (2001). Basics of Statistics. Prishtina.

Ramosaj, B. (2010). Global financial crisis and its impact on the financial system of Kosovo. Munich Personal RePEc Archive, pp. 1 - 12.

RIInvest Institute. (2009). Improving the Corporate Goverance and Transparency in Kosovo. Prishina: Rllnvest Institute \& The Center for International Private Enterprise (CIPE), Washington D.C.

World Bank Report. (2013). Republic of Kosovo 2013 Article IV Consaltation: IMF Country Report No. 222. Washington D.C: IMF: Publication Services.

World Bank Report. (2013). Republic of Kosovo: Financial System Stability Assessment, IMF Country Report No. 13/99 . Washington D.C: IMF: Publication Service.

World Bank Report. (2015). The World Bank Country Office in Kosovo. Prishtin: World Bank (Office in Kosovo): Publication Service.

Zhuang J. et.al. (2009). Financial Sector Development, Economic Growth, and Poverty Reduction: A Literature Review. Asian Development Bank Economics Working Paper Series, No.173.

Zogjani, J. \& Kelmendi, M. (2015). Banking Efficiency in Kosovo during the Global Financial Crisis. Academic Journal of Interdisciplinary Studies, 4 (2), pp. 367 - 375.

\section{Appendixes}

Appendix 1/A Data descriptions for analysis remittance

\begin{tabular}{|c|c|c|c|c|}
\hline Year & Economic Growth (EG) & Financial Sector(FS) & Inflation Rate (IR) & Exchange Rate (REER) \\
\hline 2008 & 5.4 & 3.8 & 9.35 & 105.1 \\
\hline 2009 & 3.5 & -5.5 & -2.41 & 102.2 \\
\hline 2010 & 3.3 & -0.2 & 3.48 & 104.8 \\
\hline 2011 & 4.4 & 0.1 & 7.34 & 105.8 \\
\hline 2012 & 2.5 & 3.5 & 2.48 & 106.6 \\
\hline 2013 & 3.1 & 2.6 & 1.76 & 107.2 \\
\hline 2014 & 2.7 & 12.2 & 0.4 & 106.1 \\
\hline
\end{tabular}

Source: Economic Growth - CBK 2014; Financial Sector - CBK 2014; Inflation Rate - World Bank: World Indicators; Exchange Rate Financial Stability Report, CBK 2014;

Appendix 1/B Variable Descriptions and Sources for data analysis

\begin{tabular}{|l|l|l|}
\hline Variable & Description & Source \\
\hline $\begin{array}{l}\text { Economic Growth } \\
\text { (EG) }\end{array}$ & $\begin{array}{l}\text { Economic Growth is defined as the value of the total final output (of all goods and } \\
\text { services) that is produced in a one year within a country's boundaries and the growth / } \\
\text { decrease of Real GDP is expressed as a percent (\%). }\end{array}$ & $\begin{array}{l}\text { Annual Report of CBK, } \\
2014\end{array}$ \\
\hline $\begin{array}{l}\text { Financial Sector } \\
\text { (FS) }\end{array}$ & $\begin{array}{l}\text { Financial Sector includes financial services to commercial and retail customers. This } \\
\text { sector includes banks, investment funds, insurance companies and real estate. }\end{array}$ & $\begin{array}{l}\text { Annual Report of CBK, } \\
2014\end{array}$ \\
\hline Inflation Rate (IR) & $\begin{array}{l}\text { Inflation, costumer price measures changes in the price level of a market of consumer } \\
\text { goods and services purchased by households within annual period (annual \%) }\end{array}$ & $\begin{array}{l}\text { World Bank: World } \\
\text { Development Indicators }\end{array}$ \\
\hline $\begin{array}{l}\text { Exchange Rate } \\
\text { (REER) }\end{array}$ & $\begin{array}{l}\text { The weighted average of a country's currency relative to an index of other major } \\
\text { currencies adjusted for the effects of inflation. }\end{array}$ & $\begin{array}{l}\text { Financial Stability } \\
\text { Report of CBK, 2014 }\end{array}$ \\
\hline
\end{tabular}

Source: Author estimations 